\title{
The Effect of Leadership Style, Work Motivation, Organizational Culture on Employee Performance in Public Health Centers Subdistrict Kalideres
}

\author{
Devi Mayasari ${ }^{1}$, Charles Bohlen Purba ${ }^{2}$ \\ ${ }^{1}$ Master of Management, Mercu Buana University, Jakarta, Indonesia \\ ${ }^{2}$ Lecturer of Postgraduate, Mercu Buana University, Jakarta, Indonesia
}

\begin{abstract}
This study aims to measure the leadership style, work motivation and organization on the employee performance of the Public health centers sub-district kalideres. This research is quantitative. The population is all employees. The sampling technique was using nonrandom sampling, namely saturated samples with a total of 126 employees. The research data were analyzed using multiple linear regression. The results of the t-test for the variable leadership style, work motivation and organization culture are partially positive and significant towards employee performance. The results of the F-test for the variables of leadership style, work motivation and organizational culture are simultaneously significant on employee performance. Suggestions for further research are to include other factors that have a strong influence in shaping employee performance.
\end{abstract}

Keywords:- Leadership Style, Work Motivation, Organizational Culture, Employee Performance

\section{INTRODUCTION}

Human resources in organizations based on public health services are focused on performance issues, approaches that are generally used to motivate patients and to build optimal employee performance. The need for health services for all elements of society in Indonesia is very high. Based on information according to BPJS Health in 2014, 121.6 million participants until 2016 were recorded at 171.9 million. From this figure, we can conclude that the public's need for health services is high. The Ministry of Health of the Republic of Indonesia continues to launch health programs from upstream to downstream so that health programs with a wide reach in Indonesia can be felt. Health services from urban to remote rural areas are needed by stakeholders. which are mutually integrated, starting from policies, regulations, to facilities and infrastructure that must be fulfilled as a support for carrying out health for the public. The main gate in providing services health society is the health center, and of course source owned should fit in with the Competence standard which required the organization. Public health centers sub-district kalideres, West Jakarta Administration as an organization engaged in the ministry of health in which the human resource element is filled with a variety of professions and success for the achievement of the set would not be separated from pe ran employees as an important asset in the organization. Based human resources in the company is a driving force throughout the activities, case indicates without power labor then Public health centers sub-district kalideres activity can not take place as it should. Rate performance is a method of in employee performance,because with their evaluation of the performance will know to shellac measuring of employees who are already working as intended that target them. In addition to the feedback from the judged performance will motivate employee to develop and exploit the capabilities employees. Thus the performance of health center staff will go hand in hand with the work culture and understandable whole value of the as personalities organization good perception can affect performance of employees .

The Public health centers sub-district kalideres is committed to providing the best health services to health service users, improving facilities and infrastructure that keep up with the times today. In addition, the Public health centers sub-district kalideres also optimizes health programs to be absorbed properly so that health services inside and outside the building can be optimized as well as maybe. Health implementation of the Public health centers sub-district kalideres is not solely for getting as much profit as possible, the orientation of the Public health centers subdistrict kalideres is aimed at being part of the regional government as the state's responsibility for the needs of the community in health services .

The high expectation of this company actually requires every employee to provide the best performance for the continuity of positive growth for the company. Employee performance is an important factor in every company. Of course, having employees with good performance makes it easier for companies to achieve the targets that have been set. Based on the information obtained from the Kalideres District Health Center Management, it is known that the individual performance results are shown in the table below 
ISSN No:-2456-2165

\begin{tabular}{|c|c|c|c|c|}
\hline \multirow{2}{*}{ No. } & \multirow{2}{*}{ Statement } & \multicolumn{3}{|c|}{ Results\% } \\
\cline { 3 - 5 } & & $\mathbf{2 0 1 7}$ & $\mathbf{2 0 1 8}$ & $\mathbf{2 0 1 9}$ \\
\hline 1 & Service Orientation & 98.92 & 98.88 & 98.77 \\
\hline 2 & Integrity & 98.62 & 98.72 & 97.32 \\
\hline 3 & Cooperation & 98.57 & 98.70 & 97.91 \\
\hline 4 & Commitment & 97.96 & 98.69 & 97.66 \\
\hline 5 & Work Discipline & 98.35 & 98.40 & 97.84 \\
\hline
\end{tabular}

Table 1: - Data of Increase \& Decrease in Performance Individual (\%)

Source: Subdistrict Health Center Personnel Data Kalideres (2019)

Overall, the data on the increase and decrease in individual performance in 2017, 2018, 2019 have differences that are not too far away, but the decline in performance appraisals in 2019 has changed in all assessment indicators. Assessment of employee indicators include service orientation, integrity, cooperation, commitment, and work discipline. Referring to the secondary data that has been described above, the performance of employees is not optimal at the Public health centers sub-district kalideres, then a pre-survey was carried out to 30 employees at the Public health centers sub-district kalideres Based on the results of the prequestionnaire at Public health centers sub-district kalideres that there are $6 \mathrm{f}$ actors that influence the performance of employees, namely: work motivation, leadership style, organization culture, work environment, competence and work discipline. These factors were then determined to be the most dominant actors influencing the performance of employees by conducting a pre-survey through distributing questionnaires to 30 employees at the Public health centers sub-district kalideres. Increasing organizational performance cannot be separated from the role of leaders in the organization. The leader sets goals, plans, organizes, moves and controls all resources owned, leadership style is the key a management. The leader must be a good role model for subordinates.

\begin{tabular}{|c|c|c|c|c|c|c|}
\hline No & Statement & SS & S & TS & STS & Total Score \\
\hline 1 & $\begin{array}{c}\text { Leaders demand work results with } \\
\text { perfect performance from employees } \\
\text { without conditions }\end{array}$ & 20.00 & 60.00 & 13.33 & 6.67 & 100.00 \\
\hline 2 & $\begin{array}{c}\text { Leaders provide opportunities for } \\
\text { employees to express suggestions, } \\
\text { considerations and opinions }\end{array}$ & 20.00 & 13.33 & 53.33 & 13.33 & 100.00 \\
\hline 3 & $\begin{array}{c}\text { Leadership decisions cannot be } \\
\text { changed }\end{array}$ & 26.67 & 40.67 & 16.67 & 16.67 & 100.00 \\
\hline
\end{tabular}

Table 2: - Leadership Style Pre-Survey Results

Source: Results data processing Pre survey (2019)

Table 2 shows the pre-survey results of 30 respondents, there are results of $60.00 \%$ of respondents agree that the leader demands perfect results. Then the leadership did not provide the opportunity for employees to give suggestions or opinions is $53,33 \%$. In providing the workload, the leader must listen to the suggestions or opinions of his subordinates so that good communication can occur to achieve work targets .

From the results of interviews at the Personnel Section of the Public health centers sub-district kalideres, leadership style problems like this tend to require employees to achieve perfect targets, employee dissatisfaction with leadership styles like this has an impact on decreasing employee performance. If the performance decreases, it can impact the termination of the employment relationship at the Public health centers sub-district kalideres with employees.

Leaders have the ability to deal with problems that arise, whether they are related to the organization or employees, so that good relationships are formed between employees and leaders. A good leader when leading employees, can increase work motivation for the worker himself. 
ISSN No:-2456-2165

\begin{tabular}{|c|c|c|c|c|c|c|}
\hline No. & Statement & SS & S & TS & STS & Total Score \\
\hline 1 & $\begin{array}{c}\text { My ideas and ideas are well } \\
\text { accepted in the work environment }\end{array}$ & 16.67 & 13.33 & 50.00 & 20.00 & 100.00 \\
\hline 2 & $\begin{array}{c}\text { I always try to gain insight in } \\
\text { achieving work targets }\end{array}$ & 20.00 & 46.67 & 16.67 & 16.67 & 100.00 \\
\hline 3 & $\begin{array}{c}\text { I take time to build social } \\
\text { relationships with each other in } \\
\text { the work environment }\end{array}$ & 16.67 & 27.78 & 53.33 & 10.00 & 100.00 \\
\hline
\end{tabular}

Table 3:- Pre-Survey Results of Motivation Work

Source: Results of data processing Prasurvey (2019)

Work Motivation also affects employees in the sustainability of their performance. Based on the results of pre- survey respondents on Work Motivation, the factors of ideas and ideas of employees are less accepted in the work environment by $50.00 \%$. From the results of the presurvey in carrying out tasks in achieving organizational goals, employee involvement is needed for decision making or contributing to ideas. This causes low self-motivation to achieve a target at work and many employees who come are not in accordance with the SOP .

From the results of secondary data shows that the decline in self-motivation to hose ka $\mathrm{h}$ more advanced and $m$ otivasi good work can affect the implementation of the organizational culture, where culture organization is the identity of the company, to manage its sustainability performance.

\begin{tabular}{|c|c|c|c|c|c|c|}
\hline No. & Statement & SS & S & TS & STS & Total Score \\
\hline 1 & $\begin{array}{c}\text { I was asked by my boss to have } \\
\text { the initiative in doing tasks }\end{array}$ & 16.67 & 13.33 & 50.00 & 20.00 & 100.00 \\
\hline 2 & $\begin{array}{c}\text { I charged into a compact unit } \\
\text { labor members and } \\
\text { reliable in 's objectives } \\
\text { result optimal }\end{array}$ & 20.00 & 46.67 & 16.67 & 16.67 & 100.00 \\
\hline 3 & $\begin{array}{c}\text { Leaders provide direction and } \\
\text { attention in carrying out work for } \\
\text { employees }\end{array}$ & 16.67 & 27.78 & 53.33 & 10.00 & 100.00 \\
\hline
\end{tabular}

Table 4:- Pre-Survey Results Organizational Culture

Source: Results data processing Prasurvey (2019)

Based on the results of survey respondents, the lack of direction from the leader of $53.33 \%$ indicates a lack of harmony in the relationship between leaders and subordinates.

The description above is a concern for researchers to conduct research on employee performance. then conducted a study entitled "The Effect of Leadership Style, Work Motivation and Organizational Culture on Employee Performance at the Public health centers sub-district kalideres ".

\section{THEORETICAL REVIEW}

\section{A. Employee Performance}

Performance according to Kasmir (2016: 182) performance is results of work and behavior work that has been achieved in completing several tasks and responsibilities given in a certain period. Gibson et. all (1995) defines performance as records the results of production and employment or an activity over a period of time specific. Organizational performance can be seen from performance of employees, therefore the company demands of its employees to show optimal performance. Performance HR is an term of the word Job Performance ((actual performance or achievements achieved by individuals, Mangkunegara (2016: 64). Definition of performance according to Wirawan (2015: 5), the output produced by the indicators of a profession's job within a certain time. The term performance is used to show output firms, tools, management functions (production, financial marketing), or workers' output.

\section{B. Leadership Style}

Leadership as a determinant of company goals must be able to respond to today's developments. The leadership style must follow the times. The leadership style is very important because it reflects to influence the employees. According to Gibson in Hasan Samsudin (2018), leadership style is a way for a leader to influence the behavior and thoughts of his subordinates so that they are able to carry out tasks in order to achieve organizational goals. Rivai (2014: 42) says that leadership style is a collection of characteristics used by leaders to influence subordinates so that organizational goals are achieved or it can also be said that leadership style is a pattern of behavior that is liked and is often applied by a leader. 


\section{Work Motivation}

According to Rivai (2015: 608) Motivation is an encouragement that can spur employees to work hard so that they can achieve their goals. Meanwhile, Mangkunegara (2017) Work Motivation is a condition or energy that moves employees directionally to achieve organizational goals. Basically the company expects its employees to work actively and strive to achieve the desire to achieve optimal results in work, one of the most important tasks of a leader is to motivate employees to influence attitudes and work behavior as desired, the leader must understand the nature and motives that drive employees want to work hard for the company.

\section{Organization Culture}

According to Robbins (2015) organizational culture is a system of shared meaning owned by members that makes the organization different from others. Meanwhile, according to Sedarmayanti in Harun Samsudin (2018) organizational culture is the belief in values and attitudes that arise in the organization. Organizational culture reflects the nature and characteristics contained in the work environment and is created because of the organizational activities carried out. Meanwhile, according to Umar (2010: 207), organizational culture is a shared belief and value system taken from the founder's basic philosophy which then interacts into norms where these norms are used as guidelines for how to think and behave.

\section{E. Framework}

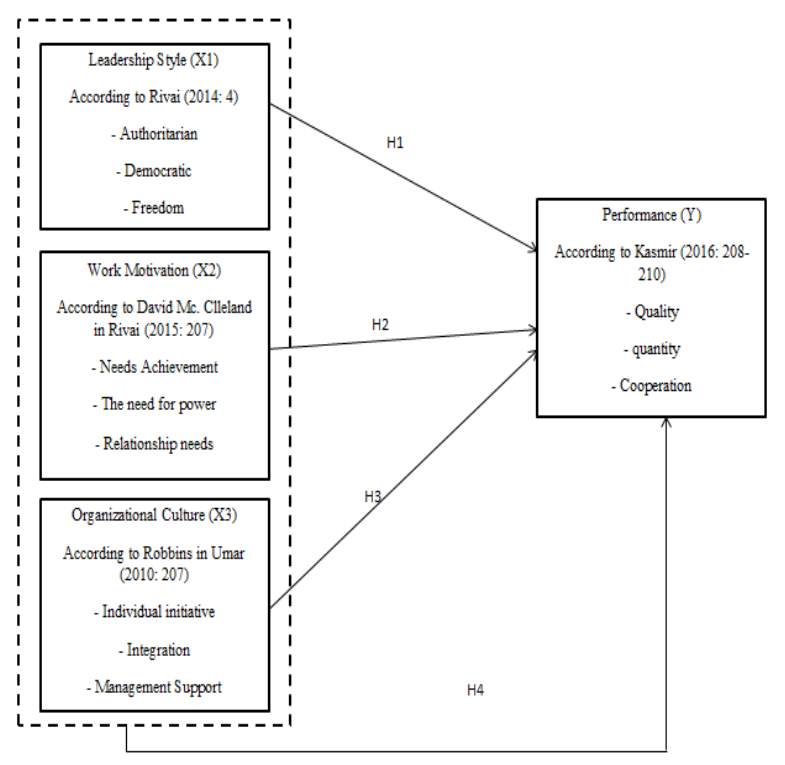

Fig 1:- Conceptual Framework

\section{F. Hypothesis}

From the theoretical framework described above, the authors propose a hypothetical s as follows:

H1: Leadership style has a positive and significant effect on employee performance at the Public health centers subdistrict kalideres

$\mathrm{H} 2$ : Work motivation has a positive and significant effect on employee performance at the Public health centers subdistrict kalideres.
H3: Organizational culture has a positive and significant effect on employee performance at the Public health centers sub-district kalideres

H4: Leadership style, work motivation and organizational culture have a positive and significant effect simultaneously on employee performance at the Public health centers subdistrict kalideres

\section{METHODOLOGY}

This research is a type of research analysis causal approach kuantitative aimed at testing hypotheses about influence of one or several variables (independent variable) on the other variable (the dependent variable). The research method used was a sample survey with a questionnaire form filled with by the employees of the Public health centers sub-district kalideres.

\section{A. Population and Sample}

The population in this study were all employees of the Public health centers sub-district kalideres. In this research, the type of sampling used is Non-Probability Sampling, namely Convenience Sampling, this sampling is based on spontaneous anyone who happens to be met within the scope of work of the Kalideres District Health Center and is willing to fill out the questionnaires in the distribute to various units to be taken as a sample. In determining the size of the study sample, the slovin formula was used (Sevilla, Consuelo G. Et.al, 2007).

\section{B. Data Collection Method}

In this study, the authors conducted several data collection methods including questionnaires, interviews and observations.

\section{Data Analysis Methods}

The data analysis method used in this study includes descriptive statistics, classic assumption tests (normality test, multicollinearity, heteroscedasticity), multiple regression analysis and hypothesis testing (T, F, R2).

\section{RESULTS AND DISCUSSION}

\section{A. Descriptive Analysis of Variables}

\begin{tabular}{|c|c|c|}
\hline \multicolumn{3}{|c|}{ Descriptive Statistic } \\
\hline & $\mathrm{N}$ & Mean \\
\hline Leadership Style & 126 & 3.59 \\
\hline Work motivation & 126 & 3.79 \\
\hline $\begin{array}{c}\text { Organizational } \\
\text { culture }\end{array}$ & 126 & 3.81 \\
\hline $\begin{array}{c}\text { Employee } \\
\text { performance }\end{array}$ & 126 & 3.98 \\
\hline
\end{tabular}

Table 5: - Results of Recapitulation Analysis Descriptive Variable Leadership Style, Work Motivation, Organization Culture and Performance Employees Source: Data Calculation Results (2020) 
The descriptive value of the employee's performance variable was obtained by an average of 3.98. So that the average value of the employee's performance variable is 3.98 in the high category. The descriptive value of the leadership style variable obtained an average of 3.59. So that the average value of leadership style variables is 3.59 in the high category. The descriptive value of the work motivation variable obtained an average of 3.79 . The descriptive value of organizational culture variables was obtained by an average of 3.81. So that the average value of the Organizational culture variable which is 3.81 in the high category.

\section{B. Validity Test}

Test the validity of the research instrument with each statement getting the value of $r$ count $>r$ table which is equal to 0.175 so that all research questionnaires are declared valid.

\section{Reliability Test}

The reliability test results show that all variables have an alpha coefficient above 0.60 , so it can be said that all measurement tools for each variable are reliable, which means that the questionnaire used in this study is reliable or reliable.

\section{Test Normality}
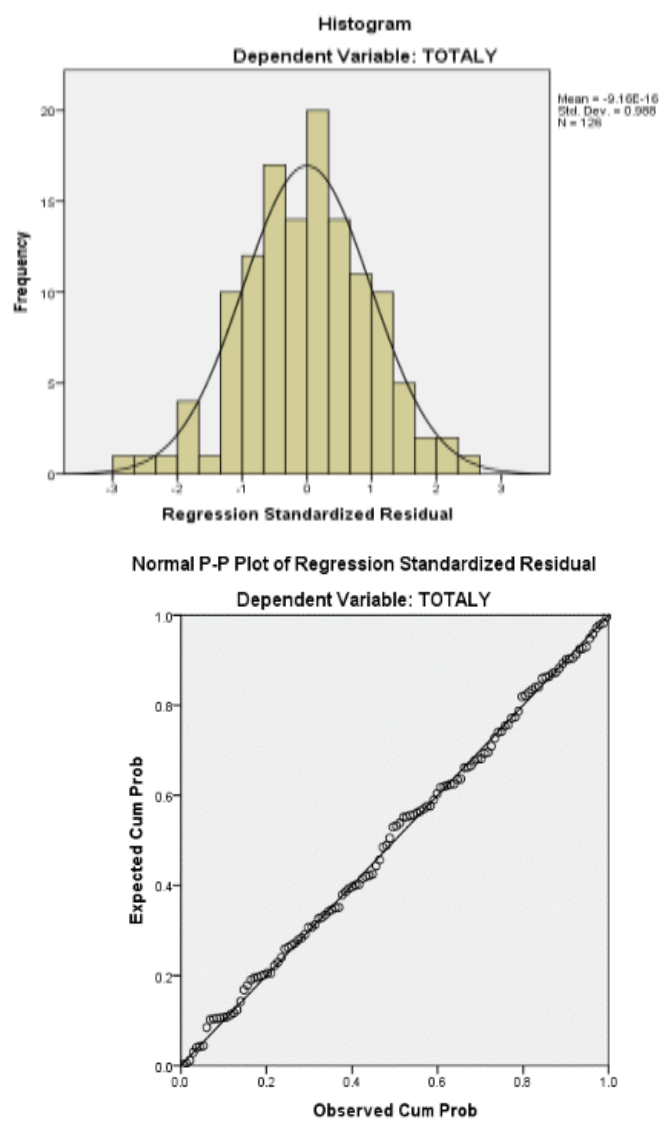

Fig 2:- Test Normality Results

Source: SPSS data processed by researchers, 2020
Based on the normal plot graph above, it is concluded that the histogram graph provides a normal distribution pattern. While the normal P-P plot of standardized residual regression shows the dots spread around the diagonal line, the distribution follows the direction of the diagonal lines. These two graphs show that the regression model is feasible because it meets the assumptions of normality.

\begin{tabular}{|c|c|c|}
\hline \multicolumn{3}{|c|}{ One-Sample Kolmogorov-Smirnov Test } \\
\hline & & $\begin{array}{c}\text { Unstandardized } \\
\text { Residual }\end{array}$ \\
\hline \multicolumn{2}{|l|}{$\mathrm{N}$} & 126 \\
\hline \multirow[t]{2}{*}{ Normal Parameters } & Mean & .0000000 \\
\hline & Std. Deviation & 2.47069273 \\
\hline \multirow{3}{*}{$\begin{array}{c}\text { Most Extreme } \\
\text { Differences }\end{array}$} & Absolute & .038 \\
\hline & Positive & .028 \\
\hline & Negative & -.038 \\
\hline \multicolumn{2}{|c|}{ Statistical Test } & .038 \\
\hline \multicolumn{2}{|c|}{ Asymp. Sig. (2-tailed) } & $.200^{\mathrm{c}, \mathrm{d}}$ \\
\hline \multicolumn{3}{|c|}{ a. Test distribution is Normal. } \\
\hline \multicolumn{3}{|c|}{ b. Calculated from data. } \\
\hline \multicolumn{3}{|c|}{ c . Lilliefors Significance Correction. } \\
\hline
\end{tabular}

Table 6:- Kolmogorov Smirnov Test Results

Source: Data SPSS processed by researchers, 2020

The results in Table 6 shows the results of that significant value (2-tailed) to test kolmogor ov Smirnov> 0.05 so that the model regression in this study distributed normal.

\section{E. Heteroscedasticity Test}

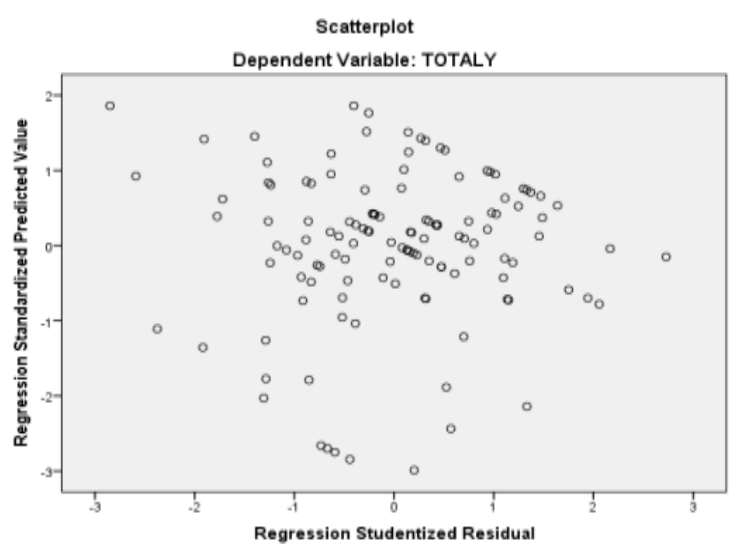

Fig 3:- Test Results Heteroscedasticity

Source: SPSS data processed by researchers, 2020

Based on Figure 3 above shows the points spread randomly and are spread above or below the number 0 on the $y$ axis, and do not have a clear pattern or do not form a pattern, it is concluded that there is no heteroscedasticity in the regression model. 


\begin{tabular}{|c|c|c|}
\hline Variable & Sig & Conclusion \\
\hline $\begin{array}{c}\text { Leadership } \\
\text { Style }\end{array}$ & 0.607 & There is no heteroscedasticity \\
\hline $\begin{array}{c}\text { Work } \\
\text { motivation }\end{array}$ & 0.073 & There is no heteroscedasticity \\
\hline $\begin{array}{c}\text { Organizational } \\
\text { culture }\end{array}$ & 0.303 & There is no heteroscedasticity \\
\hline
\end{tabular}

Table 7:- Glejser Test Results

Source: SPSS data processed by researchers, 2020

Based on the results of the heteroscedasticity test with the Glejser test in table 7, it can be concluded that each independent variable has a significance value greater than 0.05 so that heteroscedasticity does not occur.

\section{F. Multicollinearity test}

\begin{tabular}{|c|c|c|}
\hline \multirow{2}{*}{ Information } & \multicolumn{2}{|c|}{ Collinearity Statistics } \\
\cline { 2 - 3 } & Tolerance & VIF \\
\hline Style Leadership &, 559 & 1,790 \\
\hline Motivation Work &, 700 & 1,429 \\
\hline Culture Organization &, 621 & 1,611 \\
\hline
\end{tabular}

Table 8:- Results Multicollinearity Test

Source: SPSS data processed by researchers, 2020

Based on table 8 the results of the multicollinearity test, the calculation of the tolerance value shows that there are no variables that have a tolerance value $<0.10$, so in this study there is no problem in the multicollinearity test. Likewise, with the results of the calculation of the VIF value, of the three independent variables tested there was no VIF value> 10 , it can be concluded that there was no multicollinearity between the independent variables in the regression model.

\section{G. Multiple Regression Analysis}

\section{Coefficients}

\begin{tabular}{|c|c|c|c|}
\hline \multirow{2}{*}{ Model } & \multicolumn{2}{|c|}{ Unstandardized Coefficients } & \multirow{2}{*}{\begin{tabular}{|c} 
Standardized \\
Coefficients
\end{tabular}} \\
\hline & $\mathrm{B}$ & Std. Error & \\
\hline (Constant) & 2,641 & 1,270 & \\
\hline $\begin{array}{l}\text { Leadership } \\
\text { Style }\end{array}$ & .182 & .047 & .256 \\
\hline $\begin{array}{c}\text { Work } \\
\text { motivation }\end{array}$ & .183 & .031 & .353 \\
\hline $\begin{array}{l}\text { Organizational } \\
\text { culture }\end{array}$ & .396 & .061 & .408 \\
\hline
\end{tabular}

Table 9:- Results of the Multiple Regression Analysis

Source: SPSS data processed by researchers, 2020

Based on table 9 where the results of the analysis of regression obtained regression equation as follows:

$\mathrm{Y}=2,641+0,182 \mathrm{X}_{1}+0,183 \mathrm{X}_{2}+0,396 \mathrm{X}_{3}$
The constant value is 2.641 , which means that if the variable style leadership, motivation work and organizational culture is zero, then the employee performance value is 2.641. So it can be concluded that without the variable leadership style , work motivation and organizational culture, the performance employees is 2.641 unit.

B1 of 0.182 means that the variable leadership style affects the performance of employees by 0.182 or has a positive effect. If the value of the leadership style variable increases by one unit, while the other variable can still result in an increase in value of the employee performance variable by 0.182 units.

B2 of 0.183 means that the variable work motivation affects employee performance by 0.183 or has a positive effect. If the value of the work motivation variable increases by one unit while the other variable can still result in an increase in value of the variable employee performance by 0.183 units

B3 of 0.396 means that the organizational culture variable affects employee performance by 0.396 or has a positive effect. If the value of the organizational culture variable increases by one unit, while the other variable can still result in an increase in the value of the performance employee variable by 0.396 units.

H. The t-test

\begin{tabular}{|c|c|c|}
\hline Model & T & Sig. \\
\hline $\mathbf{1}$ (Constant) & 2,080 & .040 \\
\hline Leadership Style & 3,891 & .000 \\
\hline Work motivation & 5,988 & .000 \\
\hline Organizational culture & 6,530 & .000 \\
\hline
\end{tabular}

Table 10:- Analysis Results t test

Source: SPSS data processed by Researchers, 2020

The results of research obtained that $\mathrm{t}_{\text {count }}$ for $\mathrm{X}_{1}$ is 3,891 greater than $t_{\text {table }} 1,979$ with a significance of 0,000 smaller than 0.05 . Can be concluded that $\mathrm{H} 1$ is accepted, then this indicates that the variable leadership style influence positive and significant impact on the performance of employees.

The results showed that $t_{\text {count }}$ for $\mathrm{X}_{2}$ was 5,988 greater than $\mathrm{t}_{\text {table }} 1.979$ with a significance of 0.000 smaller than $0.05 . \mathrm{H} 2$ acceptable conclusion can be drawn, then this indicates that the variable motivation work positive influence and significantly to the performance of employees.

- The results of calculations obtained $t$ count for $\mathrm{X}_{3}$ of 6,530 greater than $\mathrm{t}_{\text {table }} 1.979$ with $\mathrm{a}$ significance of 0.000 smaller than $0.05 . \mathrm{H} 3$ acceptable conclusion can be drawn, then this indicates a variable of organizational culture influence positive and significant impact on the performance of employees. 
I. F-test

\begin{tabular}{|c|c|c|c|c|c|c|}
\hline \multicolumn{7}{|c|}{ ANOVA $^{\text {a }}$} \\
\hline \multirow{2}{*}{ Model } & $\begin{array}{c}\text { Sum of } \\
\text { Squares }\end{array}$ & Df & $\begin{array}{c}\text { Mean } \\
\text { Square }\end{array}$ & F & Sig. \\
\hline \multirow{2}{*}{1} & Regression & 1813,817 & 3 & 604,606 & 96,668 & $.000^{\mathrm{b}}$ \\
\cline { 2 - 8 } & Residual & 763,040 & 122 & 6,254 & & \\
\cline { 2 - 8 } & Total & 2576,857 & 125 & & & \\
\hline
\end{tabular}

Table 11:- Results of the F Test Analysis

Source: SPSS data processed by researchers, 2020

Based on table 11 of the results of the F test, it can be seen that the value of $F$ count is 96,668 and $F$ table with df1 $=3$ and df $2=126-3-1=122$ with a level of $5 \%$ then obtained Ftable of 2.68 means Fcount $>$ f table. The result $\rho=0.000<0,05$, aka $\mathrm{H} 4$ is accepted . The results of the F test can be concluded that the variables of leadership style, work motivation and organizational culture simultaneously have a significant positive effect on employee performance.

\section{J. Coefficient Determination Test}

\begin{tabular}{|c|c|c|c|c|c|c|}
\hline \multicolumn{7}{|c|}{ Model Summary ${ }^{\text {b }}$} \\
\hline Model & $\mathrm{R}$ & $\mathrm{R}$ & Square & $\begin{array}{c}\text { Adjusted R } \\
\text { Square }\end{array}$ & $\begin{array}{l}\text { Std. Error of } \\
\text { the Estimate }\end{array}$ & $\begin{array}{l}\text { Durbin- } \\
\text { Watson }\end{array}$ \\
\hline 1 & $.839^{\mathrm{a}}$ & & .704 & .697 & 2,501 & 1,585 \\
\hline
\end{tabular}

Table 12:- Results of Analysis The coefficient of determination $\left(\mathrm{R}^{2}\right)$

Source: SPSS data processed by researchers, 2020

In Table 12 the coefficient of determination (R2) shows the number 0.704 or $70.4 \%$, namely the variation in employee performance variables can be explained by leadership style, work motivation and organizational culture variables, the remaining $29.6 \%$ is explained by other variables outside of the research variables.

\section{K. Inter-Dimensional Correlation Test Results}

\begin{tabular}{|c|c|c|c|c|}
\hline Variable & Dimensions & Y.1 & Y.2 & Y.3 \\
\hline \multirow{4}{*}{\begin{tabular}{c} 
Leadership Style \\
\cline { 2 - 5 }
\end{tabular}} & $\mathrm{X} 1.1$ & 0.563 & 0.567 & 0.490 \\
\cline { 2 - 5 } & $\mathrm{X} 1.2$ & 0.467 & 0.510 & 0.568 \\
\hline \multirow{2}{*}{$\begin{array}{c}\text { Work } \\
\text { Motivation }\end{array}$} & $\mathrm{X} 2.1$ & 0.415 & 0.391 & 0.562 \\
\cline { 2 - 5 } & $\mathrm{X} 2.2$ & 0.441 & 0.579 & 0.742 \\
\cline { 2 - 5 } X2.3 & 0.297 & 0.387 & 0.625 \\
\hline \multirow{2}{*}{$\begin{array}{c}\text { Organizational } \\
\text { culture }\end{array}$} & $\mathrm{X} 3.1$ & 0.538 & 0.617 & 0.510 \\
\cline { 2 - 5 } & $\mathrm{X} 3.2$ & 0.508 & 0.564 & 0.562 \\
\cline { 2 - 5 } & $\mathrm{X} 3.3$ & 0.462 & 0.567 & 0.461 \\
\hline
\end{tabular}

Table 13:- Results of Dimensional Correlation Analysis Source: Primary Data Processed (2020)
In Table 13, the variable style leadership shows that the lowest correlation coefficient is obtained from the relationship between the dimensions of the leadership style of freedom and the quantity dimension, which is 0.391 which is included in the low correlation coefficient range. The highest correlation coefficient is obtained from the relationship between the dimensions of democratic leadership style and the dimensions of cooperation, namely 0.568 which is included in the medium correlation coefficient range. The overall correlation value of the relationship is positive, meaning that there is a directly proportional relationship between all dimensions of the leadership style variable and all dimensions of the employee performance variable.

$>$ In table 13, the work motivation variable shows that the lowest correlation coefficient is obtained from the relationship between the relationship needs dimension and the quality dimension of 0.297 which is included in the low correlation category. The highest correlation coefficient is obtained from the relationship between the need for achievement and cooperation of 0.742 which is included in the strong correlation category. The overall correlation value between the dimensions of the relationship is positive, meaning that there is a positive (directly proportional) relationship between the dimensions of work motivation and employee performance.

In Table 13, the organizational culture variable shows that the lowest correlation coefficient is obtained from the relationship between the dimensions of management support and the cooperation dimension of 0.461 which is included in the low correlation category. The highest correlation coefficient obtained from the relationship between the dimensions of the initiative with the dimensions quantitas amounted to 0.617 in category of moderate correlation. The overall correlation value between the dimensions of the relationship is positive, meaning that there is a positive (directly proportional) relationship between organization culture dimensions and the dimensions of employee performance.

\section{Results of the Discussion}

\section{> The Effect of Leadership Style on Employee Performance}

Results of testing the influence of the leadership style variable on employee performance indicate that leadership style affects the employee performance variable. This statement is evidenced by the t-count value for X1 of 3,891, which is greater than the t-table of 1.979 with a significance of 0.000 smaller than the significance level of 0.05 . It means that it can be concluded that $\mathrm{H} 1$ is accepted and Ho is rejected, so this shows that the leadership style variable has a positive and significant effect on employee performance. Leaders with authoritarian abilities, democracy and good freedom are able to encourage employees to give their best performance. 
These results are in line with previous research on the effect of job satisfaction on performance, namely from the opinion of Smith, Candace S (2017) that leadership style has a positive and significant effect on performance, and Lukertina Sihombing (2018) argues that a good leadership style provides a positive value for employee performance.

\section{$>$ The Effect of Work Motivation on Employee Performance}

The results of testing the influence of work motivation variables on employee performance indicate that work motivation has an effect on employee performance variables. This is evidenced by the value of tcount for X2 of 5,988, which is greater than $t$ table of 1,979 with a significance of 0,000 , smaller than the significance level of 0.05 . It means that it can be concluded that $\mathrm{H} 2$ is accepted and Ho is rejected, so this shows that the work motivation variable has a positive and significant effect on employee performance.

Work motivation is an encouragement to do a job. Employees who have high work motivation will work in accordance with applicable standards and according to predetermined time, require little supervision, and create a work atmosphere that is conducive to work.

This is in line with previous research by Galan Kusuma, Edy Rahardja (2018) concluded that work motivation has a positive and significant effect on employee performance.

\section{The Effect of Organizational Culture on Employee Performance}

The results of testing the influence of organizational culture variables on employee performance indicate that organizational culture has an effect on employee performance variables. This statement is evidenced by the tcount for X3 of 6,530, which is greater than the ttable of 1.979 with a significance of 0.000 smaller than the significance level of 0.05 . It means that it can be concluded that $\mathrm{H} 3$ is accepted and Ho is rejected, so this shows that organizational culture variables have a positive and significant effect on employee performance. With adherence to the rules and policies of the company, it is hoped that it can optimize the performance and productivity of employees to achieve organizational goals.

These results are also in line with Adel Mohamed Ali Shurbagi's previous research (2015) that organizational culture has a positive and significant effect. In line with these results, Sari Maysarah, Mudji Rahardjo (2015) argues that a strong organizational culture in an organization based on engagement and adaptation can improve employee performance.

\footnotetext{
> The Effect of Leadership Style, Work Motivation and Organizational Culture on Employee performance

Based on the results of the calculation, it is found that the value of $\mathrm{F}$ count is 96,668 and $\mathrm{F}$ table with $\mathrm{df1}=$ degrees of numeration, namely 3 and df $2=$ degrees of denominator $126-3-1=122$ with a level of $5 \%$, then the
}

obtained F table is 2.68 means $\mathrm{F}$ count $>\mathrm{f}$ table. The result $\rho=0.000<0.05$, then Ho is rejected and H4 is accepted. In the results of the $F$ test it can be concluded that the independent variables jointly or simultaneously affect the dependent variable significantly. Based on the analysis, it can be concluded that the variables of leadership style, work motivation and organizational culture have a positive and significant effect simultaneously on employee performance.

The results of this study are in line with Lukertina Sihombing's (2018) previous research which states that there is a significant positive effect between organizational culture on employee performance and leadership style on performance. Based on previous research, leadership style, work motivation, and organizational culture together or simultaneously have an influence on employee performance. So that if the leader has good leadership, the employee's work motivation needs are met, and also a strong organizational culture, then this will be able to improve employee performance to achieve company goals.

\section{CONCLUSIONS AND SUGGESTIONS}

\section{A. Conclusion}

$>$ Leadership Style has a significant positive effect on employee performance. This shows good leadership by providing opportunities for subordinates to provide advice and good two-way communication, this will increase employee performance.

$>$ Work motivation has a significant positive effect on employee performance. This shows that the need for achievement can increase work motivation, so that employee performance will also increase.

$>$ Organizational culture has a positive and significant effect on employee performance. This is supported by the results of the correlation test. The highest correlation coefficient is obtained from the relationship between the dimension of initiative and the dimension of work quantity.

$>$ The variables of leadership style, work motivation and organizational culture have a positive and significant effect simultaneously on the performance of Kalideres District Health Center employees. So it can be concluded that good leadership style, work motivation and organizational culture affect the increased performance of employees of Kalideres District Health Center.

\section{B. Suggestions}

$>$ Public health centers sub-district kalideres management should communicate well in two ways, for example, such as conducting morning briefings before health centers services, increasing the quantity by working more quickly and efficiently.

$>$ Public health centers sub-district kalideres management should further enhance cooperation among employees by carrying out activities that involve all employees. This is expected to increase cohesiveness and good cooperation between employees so as to minimize errors in work and be able to work in accordance with 
the standards of the Public health centers sub-district kalideres.

$>$ Public health centers sub-district kalideres management should provide support to employees, efforts that can be done are with the leadership to provide direction to employees in carrying out their duties and also the leadership and also provide input / suggestions if problems occur related to work so that this will provide good work results between leaders and colleagues.

The hope of the authors is that further research can involve and dig deeper related to other variables that affect employee performance such as the work environment obtained from the results of the pre-survey research. The high influence of Organizational Culture on Employee Performance found in this study opens the possibility of other influences from other variables.

\section{REFERENCES}

[1]. Al Rahbi, Dana; Khalid, Khalizani; Khan, Mehmood (2017). The Effects Of Leadership Styles on Team Motivation'. Academy of

Strategic Management Journal;

Arden Vol. 16, Iss. 3, (2017): 1-14

[2]. Al-Sada, Maryam; Al-Esmael, Bader; Mohd Nishat Faisal.(2016) Influence of organizational culture and leadership style on employee satisfaction, commitment and motivation in the educational sector in Qatar',.EuroMed Journal of Business

[3]. Arifin, Syamsul. 2012. Leadership Ilmu dan Seni kEpemimpinan. Jakarta: Mitra Wacana Media.

[4]. Bader Al-Esmael and Mohd. Nishat Faisal (2016) Influence of organizational cultureand leadership style on employee satisfaction, commitment and motivation in the educational, The current issue and full text archive of this journal is available on Emerald Insight.

[5]. Chen-Tsung Kuo (2019) Principals Transformational Leadership and Teacher' Work Motivation : Evidence From Elementary Schools In Taiwan, The International Journal of Organizational Innovation Volume 11 Number 3, January 2019

[6]. Galan Kusuma, Edy Rahardja (2018),'Pengaruh Gaya kepemimpinan Transformal dan Motivasi Kerja Terhadap Kinerja Karyaawan (Studi Pada Karyawan PD BPR BKK Taman Pemalang)', Diponegoro Journal of Management, 2018 ejournal3.undip.ac.id Vol 7 nomor 2 Tahun 2018

[7]. Ghozali, Imam. (2013). Aplikasi Analisis Multivariate dengan Program IBM SPSS 21 Update PLS Regresi. Semarang: Badan Penerbit Universitas Diponegoro

[8]. Kasmir. 2016. Manajemen Sumber Daya Manusia (teori dan praktik). Jakarta : PT Raja Grafindo Persada

[9]. Mangkunegara, A.A.A.P. 2014. Kepemimpinan dan Perilaku Organisasi. Jakarta: PT. Raja Grafindo Persada
[10]._ 2015. Manajemen Sumber Daya Manusia Untuk Perusahaan . Edisike-7. Depok: PT RAJAGRAFINDO.

[11]. 2016. Manajemen Sumber Daya Manusia Perusahaan. Bandung : PT. Remaja Rosdakarya

[12]. 2017. Metode Penelitian Kuantitatif, Kualitatif, dan R\&D. Bandung : Alfabeta, CV

[13]. Maysarah, S \& Rahardjo, M 2015, 'Analisis pengaruh Budaya Organisasi, Keadilan Organisasi, dan Komitmen Organisasi terhadap OCB (Studi Pada PT Kereta Api Indonesia (Persero) Daerah Operasi 4 Semarang), Jurnal Manajemen Universitas Diponegoro, vol. 4, no.4, hal 1-14.

[14]. Nadeak, B 2017, 'Pengaruh Budaya Organisasi terhadap Organizational Citizenship Behavior Dosen di Universitas Kristen Indonesia, Journal Univeristas UKI, vol. 5, no. 1 , phal $1-10$.

[15]. Palmerston, Mark J.California Lutheran University,(2016) Understanding How Principals' Leadership Styles Influence Teacher Motivation', ProQuest Dissertations Publishing.

[16]. Parlindungan, Bernad Togu \& Purba, Charles Bohlen. (2018). Pengaruh kepemimpinan, kompensasi dan motivasi kerja terhadap kinerja karyawan di PT. Citra Makmur Sejahtera. Jurnal SWOT. Vol. VIII No.2. hal 306-317

[17]. Patimah, Siti (2017), Leadership Styles, Motivation Achievers and Quality in Cultural Teaching, .European Research Studies; Anixis Vol. 20, Iss. 3A, (2017): 278-29

[18]. Purba, charles bohlen., Primayoga kukuh. 2017.Pengaruh Motivasi dan Kohesitivitas kelompok terhadap kinerja pendamping program keluarga harapan $(\mathrm{PKH})$ di Kota Bekasi,Universitas Mercu Buana Jurnal Ilmiah Manajemen Bisnis, Volume 3, No. 02, Juli 2017

[19]. Purba, charles bohlen., Dafit Fitria Saduk 2018. The Influence Of Leadership Compensation and Workload on Turnover Intention at PT. Karya Utama Perdana. International Journal Scholars Bulletin Management (IJSBM). Volume 4, Issue 12, December 2018, Hal. 874-881

[20]. Sanhaji, A, Soetjipto, BE \& Suharto 2016, 'Pengaruh Keadilan organisasi dan Budaya Organisasi terhadap Perilaku Kewargaan Organisasi melalui Komitmen Organisasi dan Kepuasan Kerja', Jurnal Pendidikan, vol. 1, no.5, hal.917-926.

[21]. Sekaran, Uma dan Roger Bougie, (2017), Metode Penelitian untuk Bisnis:

[22]. Sihombing Lukertina (2018),'Pengaruh Budaya Organisasi dan Gaya Kepemimpinan terhadap kinerja karyawan', Jurnal Ilmiah Manajemen Bisnis, Volume 4, No. 02, Juli 2018

[23]. Sihotang, Gideon and DJASTUTI, Indi and Rahardjo, Mudji (2016), 'Analisis Budaya Organisasi, Gaya Kepemimpinan dan Kepuasan Kerja terhadap kinerja',Diponegoro Journal of Management, 2018 ejournal3. 
[24]. Smith, Candace $S$ (2017),Leadership Style and Leadership Education: A Phenomenological Study of Nurse Leader and Frontline Charge Nurse Perceptions of Leadership Style and Leadership Education in Hospitals', ProQuest Dissertations Publishing, 2017

[25]. Sugiyono.(2009) 2017. Metode Penelitian Kuantitatif, Kualitatif, dan R\&D. Bandung : Alfabeta, CV

[26]. Suliyanto. (2018). Metode Penelitian Bisnis. Yogyakarta: CV. Andi Offset

[27]. Syaifuddin, STIE Sebelas April, 'Pengaruh Setres Kerja dan Kepemimpinan Transformasi tentang Pekerjaan Motivasi dan Implikasi Karyawan', Academy of Strategic Management Journal, Volume 15, Special Issue 3, 2016.

[28]. Veithzal Rivai Zainal, S. 2011, Manajemen Sumber Daya Manusia untuk Perusahaan: dari Teori ke Praktik, Jakarta : Raja Grafindo Persada

[29]. Wirawan. (2017). Manajemen Sumber Daya Manusia Indonesia. Jakarta: PT Raja Grafindo Persada. 